HEJ (Home Economics Journal). Vol. 1, No. 2. October 2017, 39-46

ISSN 2579-4272 (printed), ISSN 2579-4280 (online)

\title{
PENGEMBANGAN KOMIK ANIMASI DIGITAL UNTUK SIMULASI AMERICAN SERVICE
}

\author{
Prihastuti Ekawatiningsih', Wika Rinawati ${ }^{2}$, Ilmawan Mustaqim ${ }^{3}$ \\ ${ }^{1,2}$ Program Studi Pendidikan Teknik Boga \\ 1,2,3 Universitas Negeri Yogyakarta \\ Email: prihastuti@uny.ac.id
}

\begin{abstract}
ABSTRAK
Penelitian ini bertujuan untuk mengembangkan media komik animasi untuk simulasi pembelajaran melayani makan dan minum (food and beverage service) di restoran, khususnya materi American Service. Penelitian dilakukan untuk merancang alur cerita American Service dalam bentuk komik, khusunya memilih materi American Service yang sesuai, membuat alur cerita dan mengembangan komik American Service. Penelitian ini menggunakan metode penelitian dan pengembangan model 4D (define, design, developt and dissemination). Define dilakukan untuk menetapkan materi pembelajaran yang dapat disimulasikan dalam cerita komik. Desain dibuat bentuk komik dan developt dilakukan untuk menguji dan memperbaiki komik sekaligus menambah animasi. Disseminasi dilakukan dengan media on-line melalui situs internet Jurusan Pendidikan Teknik Boga dan Busana. Subjek penelitian untuk menguji produk ditetapkan 5 pakar dan 40 orang calon pengguna. Metode pengumpulan data pengujian produk menggunakan teknik Delphi, Focus Group Discussion (FGD) dan observasi tampilan komik. Hasil pengujian dianalisis secara deskriptif kuantitatif dan kualitatif. Penelitian menghasilkan rancangan media komik digital American service dengan sistem American Service, menggunakan aplikasi Comicize-thecomics maker dan Photo talks:speech bubbles. Pada tahap ini dapat diidentifikasi materi untuk pengembangan komik berupa American service.
\end{abstract}

Kata Kunci: american service, animasi digital, komik

\section{PENDAHULUAN}

Bisnis hotel dan restoran berkembang pesat di wilayah Yogyakarta. Menurut data
Badan Pusat Statistik (BPS) DIY, pada tahun 2014, jumlah hotel di wilayah Yogyakarta tercatat pada tabel 1berikut ini

Tabel 1. Jumlah Akomodasi, Kamar dan Tempat Tidur Hotel menurut Kabupaten/Kota di D.I. Yogyakarta, tahun 2015

\begin{tabular}{|l|r|r|r|r|r|r|}
\hline \multirow{2}{*}{ Regency/City } & \multicolumn{4}{|c|}{ Classified Hotel } & \multicolumn{3}{c|}{ Non Classified Hotel } \\
\cline { 2 - 8 } & $\begin{array}{c}\text { Accomo- } \\
\text { dation }\end{array}$ & \multicolumn{1}{|c|}{ Rooms } & \multicolumn{1}{c|}{ Beds } & $\begin{array}{c}\text { Accomo- } \\
\text { dation }\end{array}$ & \multicolumn{1}{c|}{ Rooms } & \multicolumn{1}{c|}{ Beds } \\
\hline 1. Kulonprogo & - & - & - & 26 & 474 & 526 \\
\hline 2. Bantul & 1 & 71 & 119 & 261 & 2161 & 2618 \\
\hline 3. Gunungkidul & 1 & 46 & 52 & 69 & 671 & 756 \\
\hline 4. Sleman & 26 & 3391 & 5147 & 363 & 4128 & 5748 \\
\hline 5. Yogyakarta & 57 & 5255 & 8391 & 362 & 6397 & 10248 \\
\hline Jumlah/Total & $\mathbf{8 5}$ & $\mathbf{8 7 6 3}$ & $\mathbf{1 3 7 0 9}$ & $\mathbf{1 ~ 0 8 1}$ & $\mathbf{1 3 ~ 8 3 1}$ & $\mathbf{1 9 ~ 8 9 6}$ \\
\hline Tahun 2014 & 71 & 6864 & 10725 & 1067 & 13624 & 19860 \\
\hline
\end{tabular}

Perkembangan jumlah hotel berdampak pada penambahan jumlah kebutuhan tenaga kerja perhotelan. Hotel berbintang sedikitnya memiliki 9 departemen yang masing-masing 
membutuhkan sumberdaya manusia yang kompeten di bidang perhotelan. Departemendepartemen yang terdapat di hotel yaitu: (1) Marketing, (2) Front Office, (3) Housekeeping. (4) Laundry, (5) Engineering \& Maintenance, (6) Food \& Beverage, (7) Finance, (8) Human resource development, dan (9) Security, Food \& Beverage Depatement mempunyai peranan untuk memproduksi, menyiapkan dan melayani makan dan minum. Departement. Food \& Beverage terdiri dari dua bagian yaitu bagian production dan service (pelayanan).Kebutuhan tenaga kerja Food \& Beverage disuplai oleh lembaga pendidikan seperti SMK paket keahlian Perhotelan, Akademi Pariwisata, Sekolah Tinggi Pariwisata, lembaga kursus pariwisata, dll. Program studi Pendidikan Teknik Boga menghasilkan calon guru SMK bidang keahlian Pariwisata sehingga lulusannya diharapkan mampu menguasai kompetensi $F B$ service tersebut untuk mensuplai kebutuhan tenaga kerja di hotel dan restoran.

Praktikum food and beverage (FB) service memerlukan biaya yang mahal untuk pembelian bahan dan alat-alat yang sesuai standar. Media pembelajaran diharapkan dapat mengurangi biaya bahan dan alat praktikum karena serangkaian kegiatan praktikum tersebut dapat disimulasikan dengan gambar

dalam bentuk komik digital dan gambar bergerak dalam bentuk film kartun. Komik digital semakin populer di kalangan remaja. Hal ini dapat diketahui dari komik-komik yang dihasilkan dan program-program aplikasi yang digunakan untuk membuat komik semakin banyak ditemui di internet.

Teknologi informasi dan komunikasi berkembang sangat pesat. Sampai saat ini sudah banyak tersedia software untuk pembuatan komik dan film kartun animasi yang mudah untuk diaplikasikan. Beberapa sofware yang cocok untuk digunakan dalam pembuatan komik FB service dan etika makan antara lain: adobe photoshop CC, comic creator, corel painter, dan comic life. Alur cerita yang sudah dirancang dalam komik kemudian ditambah dengan animasi sehingga menjadi film kartun.
Software yang cocok untuk pengembangan film kartun FB service dan etika makan adalah Anime studio, fotomorph, dan muvizu.

Materi pembelajaran yang disusun dalam bentuk gambar dapat lebih mudah dipelajari daripada yang berbentuk tulisan biasa. Dengan bantuan media, mahasiswa diharapkan lebih mudah mengingat kembali materi pelajaran FB service tanpa harus mengeluarkan biaya praktikum berulang-ulang. Media simulasi FB service juga diharapkan dapat membantu proses pembelajaran praktikum di SMK atau lembaga kursus yang kekurangan alat dan bahan praktikum. Oleh sebab itu, dalam penelitian ini perlu dikembangkan media simulasi pelayanan makan dan minum di hotel dan restoran menggunakan media gambar cetak (komik) dan media gambar bergerak dalam bentuk film kartun.

Pelajar dan mahasiswa banyak yang lebih menguasai teknologi digital daripada guru atau dosennya. SD Santa Maria Kota Magelang bahkan sudah mewajibkan siswanya membuat film sebagai salah satu tugas mata pelajaran Teknologi Informasi dan Komunikasi (TIK) (Tribun News, 24/3/2015). Pengembangan media simulasi $F B$ service dan etika makan juga dapat dikemas menjadi tugas tematik pada mata kuliah Tata Hidang dan Teknologi Pembelajaran. Dalam kegiatan penelitian ini, mahasiswa akan mendapat pelatihan aplikasi software comic creator dan muvizu sebelum mereka diberi tugas membuat komik dan film animasi. Mahasiswa yang dapat menyelesaikan tugas menyusun komik dan film kartun animasi dengan baik akan diberi kesempatan untuk melanjutkannya menjadi tugas akhir skripsi (TAS).

Penelitian dirancang selama dua tahun. Pada tahun pertama, penelitian bertujuan untuk mengembangkan komik FB service dan etika makan dan tahun kedua kembangkan lagi menjadi film kartun dari naskah komik yang telah disusun sebelumnya. Dengan demikian dapat mengetahui proses pengembangan komik digital American Service dan tanggapan 
mahasiswa terhadap kelayakan isi dan tampilan gambar komik American service.

\section{METODE}

Pengembangan media simulasi FB service dilakukan dengan metode penelitian dan pengembangan. Model pengembangan mengacu pada model 4D yang merupakan akronim dari define, design, developt dan dissemination (Thiagarajan, 1974). Kegiatan penelitian tahun pertama dilakukan untuk membuat komik dengan melewati tiga tahap yaitu define, design, developt.

Tahap-tahap penelitian dan pengembangan komik dan film kartun digital dapat dijelaskan sebagai berikut:

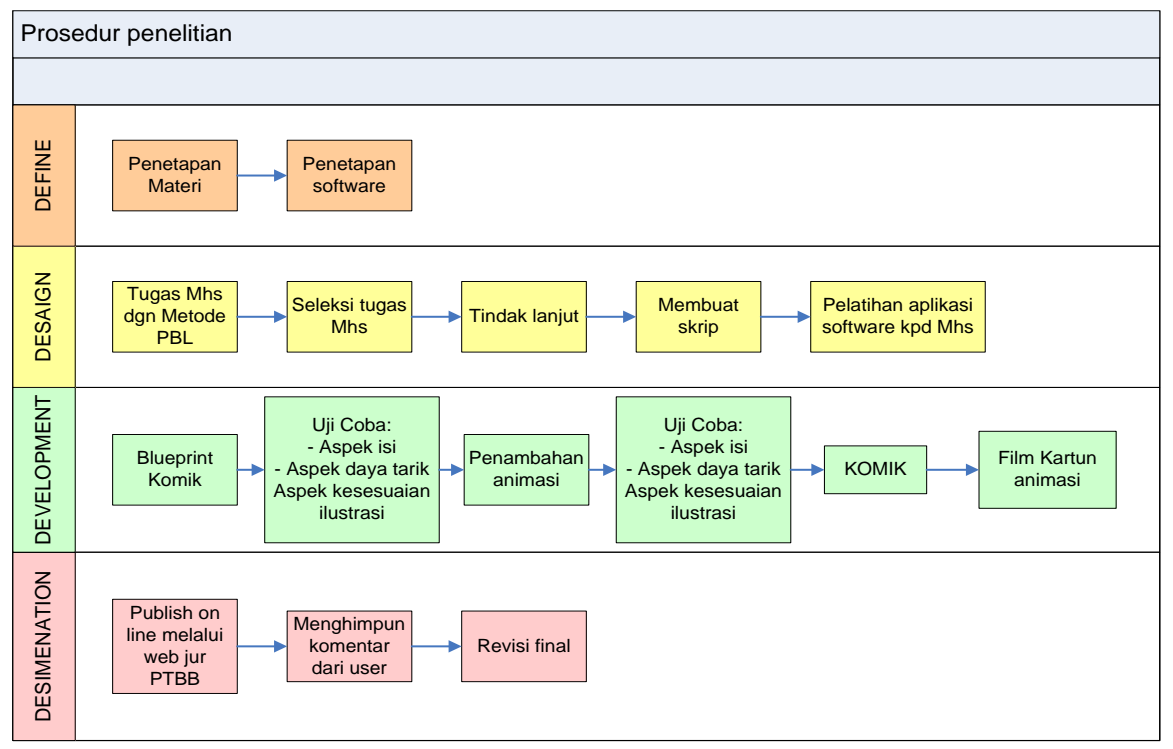

Gambar 2. Tahapan Pengembangan Komik dan Film Kartun

Define

Pada tahap awal penelitian dilakukan penetapan materi $F B$ service dan etika makan yang akan disimulasikan dengan media komik dan film kartun digital. Disisi lain juga ditetapkan software komik dan kartun yang tepat dipilih, bebas akses dan karakter sesuai untuk materi FB service dan etika makan.

\section{Design}

Setelah berhasil diidentifikasi materi FB service dan etika makan kemudian dilakukan perancangan produk media komik dan film kartun digital dalam bentuk skrip. Tabel 3. Sumber data Penelitian

\begin{tabular}{|l|c|c|c|}
\hline \multicolumn{1}{|c|}{ Kegiatan } & Sumber data & Jumlah & Metode \\
\hline Define & Buku dan software komik dan film kartun & 10 & Content analysis \\
\hline Design & Mahasiswa Boga dan TI & 40 & Delphi \\
& Dosen Boga & 4 & FGD \\
& Dosen TI & 4 & \\
\hline
\end{tabular}

Dalam tahap ini, peneliti melibatkan mahasiswa dalam tugas tematik menggunakan metode project based learning yang kompetitif antar kelompok. Hasil-hasil rancangan skript yang bagus akan ditindaklanjuti dalam proses pengembangan komik dan film kartun. Skrip mahasiswa yang terpilih dapat dilanjutkan dalam penyusunan TAS (tugas akhir skripsi) dengan tema pengembangan media komik digital food service.

Selama proses penelitian dan pengebangan dilibatkan beberapa kelompok sumberdata penelitian seperti tertera pada tabel 3 berikut ini: 


\begin{tabular}{|l|c|c|c|}
\hline Developt & Mahasiswa Boga dan TI & 40 & Projek based learning \\
& Dosen Boga & 4 & Uji terbatas \\
& Dosen TI & 4 & \\
\hline Dissemination & Masyarakat umum & Tak terbatas & Uji publik on- line \\
\hline
\end{tabular}

Rangkuman proses pengambilan data pada tabel 2 menunjukkan ada berbagai sumber data yang dilibatkan dalam penelitian ini yaitu mahasiswa, dosen dan masyarakat umum. Peran masing-masing sumber data adalah sebagai berikut:

1. Mahasiswa Pendidikan Tata Boga berperan sebagai perancang alur cerita dan skrip, pembuat komik dan film kartun serta penguji kelayakan program dari sisi isi dan tampilan,

2. Mahasiswa Teknologi Informatika berperan sebagai tutor pendamping mahasiswa Pendidikan Tata Boga dalam pembuatan komik dan film kartun serta penguji program.

3. Dosen Pendidikan Tata Boga dan Teknologi Informatika berperan sebagai pengarah dan validator ahli.

Sesuai rancangan pada Tabel 3 penggunaan setiap metode pengumpulan data dapat dijelaskan sebagai berikut:

1. Analysis content

Metode ini digunakan untuk menelusuri materi kuliah FB service dan etika makan, prosedur pembuatan komik dan film kartun, jenis-jenis karakter tokoh komik dan film kartun serta mempelajari aplikasi software yang visibel untuk digunakan.

\section{Teknik Delphi}

Teknik Delphi digunakan untuk menguji kelayakan (validasi) rancangan skrip yang disusun mahasiswa. Teknik ini digunakan karena validator memiliki waktu yang cukup untuk membaca dan memahami isi komik sehingga diharapkan dapat memberi koreksi yang cukup banyak.

\section{FGD}

Hasil-hasil validasi menggunakan teknik Delphi kemudian di bawa ke dalam forum Focus Group Discussion. Diskusi dilakukan untuk menemukan kesepakatan dari beberapa validator yang memiliki pendapat berbeda.

4. Project based learning

Project based learning diintegrasikan sebagai tugas tematik mata kuliah Teknologi Pembelajaran, Tata Hidang dan Tugas Akhir Skripsi. Project based learning digunakan untuk membuat produk dari rancangan (skrip) yang telah disusun. Metode ini diterapkan dengan cara sebagai berikut:

a. Mahasiswa membentuk tim kerja dengan kemampuan yang berbeda-beda (ahli materi, ahli membuat cerita, dan ahli program).

b. Tiap kelompok mendapat satu tugas proyek pembuatan komik atau film kartun animasi.

c. Mahasiswa merancang satu projek dari satu topik materi $F B$ service atau etika makan.

d. Mahasiswa dilatih mengaplikasikan program komik dan kartun digital

e. Mahasiswa Pendidikan Teknik Boga membuat projek yang telah dirancang dengan bimbingan mahasiswa Teknik Informatika.

Analisis data dilakukan secara deskriptif kualitatif dan kuantitatif dari data validasi dan uji publik.Rangkuman metode penelitian dalam fishbone diagram tertera pada gambar 3, berikut ini:

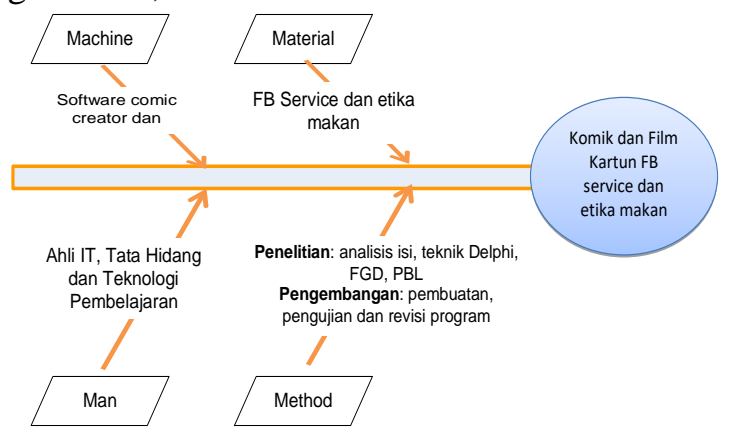

Gambar 3. Fishbone Kegiatan Penelitian

HASIL DAN PEMBAHASAN 


\section{Deskripsi Produk Pengembangan}

Penelitian pengembangan media komik dan film kartun animasi untuk simulasi pembelajaran melayani makan dan minum (food and beverage service) dibagi menjadi tiga tugas proyek pengembangan oleh mahasiswa yaitu: (1) komik digital American Food Service; (2) komik digital Russian Food

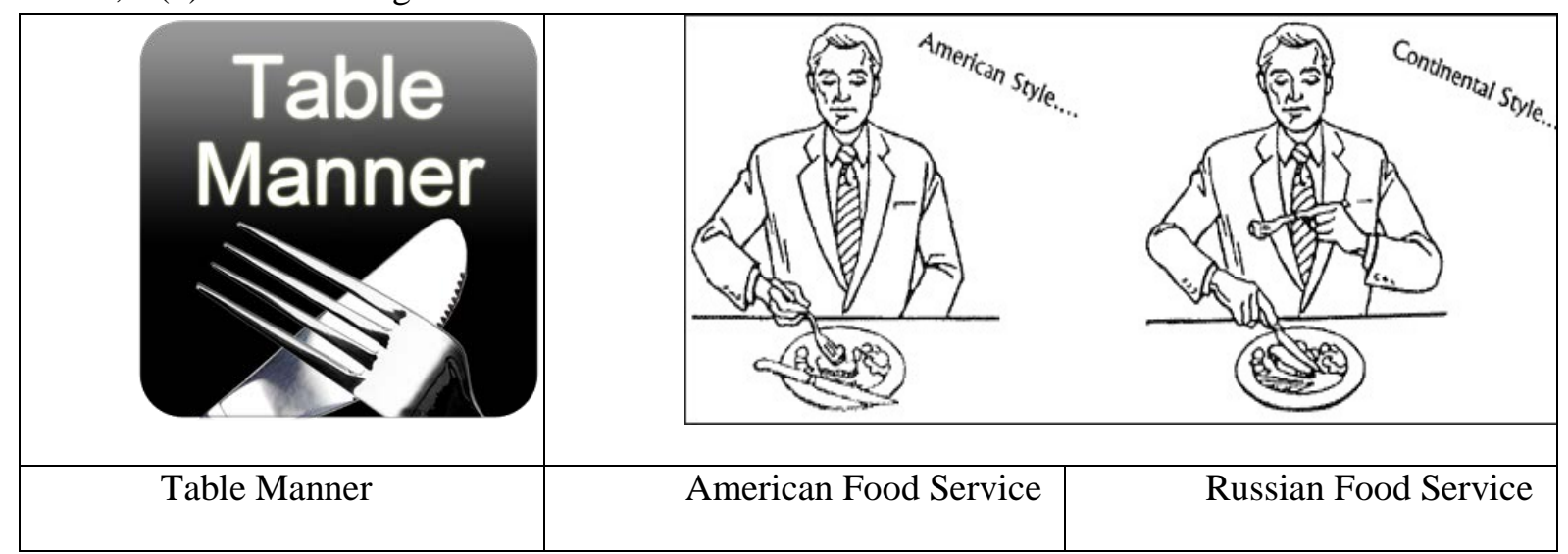

\section{Analisis Kebutuhan}

Dalam mata pelajaran Tata Hidang kelas XI terdapat 6 kompetensi dasar yaitu: (1) merancang menu (menu planning); (2) memilih dan menyiapkan peralatan makan dan minum; alat hidang serta lenan; (3) membuat lipatan serbet; (4) menata meja (table set-up); (5) menjelaskan jenis, karakteristik, dan persyaratan petugas pelayanan makan dan minum; (6) melayani makan dan minum di restoran. Kompetensi dasar Tata Hidang kelas XII ada 5 yaitu: (1) menata meja prasmanan (buffet); (2) melayani pesanan makan minum di kamar; (3) membuat minuman non alkohol; (4) membuat minuman panas; (5) membuat minuman.

Sesuai dengan definisinya, komik (comic) merupakan cerita bergambar, sehingga materi pelajaran yang dapat dikembangkan menjadi komik adalah materi yang dapat disusun dalam bentuk cerita. Dari beberapa kompetensi dasar Tata Hidang, dalam penelitian ini dipilih materi pada kompetensi dasar ke 4 dan 5 yaitu menata meja (table setup) dan menjelaskan jenis, karakteristik, dan persyaratan petugas pelayanan makan dan minum. Berdasarkan hasil analisis, media pembelajaran table set up banyak
Service; (3) media komik digital etika makan pada jamuan makan formal (table manner). Produk awal hasil pengembangan ditampilkan pada gambar berikut ini: dikembangkan dalam bentuk video dan modul, sedangkan media komik masih terbatas.

Penataan meja makan setiap negara berbeda-beda tergantung pada budaya masingmasing negara. Restoran hotel pada umumnya menggunakan dua cara penataan meja yang memiliki standar internasional yaitu American service dan Russian service. Oleh sebab itu, dalam penelitian ini ditetapkan dua materi tersebut. Berdasarkan hasil analisis, penataan meja American service dan Russian service memiliki karakteristik yang berbeda.

Dalam acara jamuan makan, terdapat tamu dan pelayan yang memiliki peran berbeda, namun keduanya harus saling memahami tata cara makan (table manner) agar tidak terjadi mis komunikasi. Dalam penelitian ini dikembangkan komik etika tamu pada jamuan makan formal. Berdasarkan hasil analisis, banyak tata cara makan formal yang harus diketahui tamu maupun pelayannya pada saat sebelum makan, pada saat makan, dan sesudah makan. Beberapa cara bahkan ada yang dinyatakan secara simbolik menggunakan peralatan makan itu sendiri seperti peletakan sendok, garpu, pisau dan serbet makan (napkin) 


\section{Design}

Dalam proses pembuatan komik, langkah-langkah yang dilakukan oleh peneliti adalah:

a) membuat peta konsep untuk merancang cakupan materi pokok yang harus ada dalam topik penataan meja (table set up) dan etika makan.

b) Setelah peta konsep disepakati oleh tim pengembang kemudian disusun alur cerita komik yang lengkap dan skenario yang berisi dialog antar tokoh c) Memilih latar belakang (back ground) pada aplikasi Comicize - the comics maker dan Photo talks: speech bubbles

d) Memilih gambar yang sesuai dengan karakter tokoh pada rancangan alur cerita.

e) Menyusun gambar sesuai dengan skenario, menambahkan teks, dan memberi warna dan effect sesuai keinginan

f) mengedit gambar dan teks sesuai saran pengguna

g) mengupload komik dan share melalui media sosial.

Hasil rancangan media komik dapat dilaporkan dalam bentuk tabel sebagai berikut

Tabel 4. Cakupan Materi Komik American service dan Table Manner

\begin{tabular}{|c|c|c|c|}
\hline Sub topik & Varians & Rincian/Uraian & \\
\hline Menu & $\begin{array}{l}\text { Appetizer, } \\
\text { soup, } \\
\text { main course, } \\
\text { dessert }\end{array}$ & & \\
\hline Alat hidang & $\begin{array}{l}\text { Appetizer, } \\
\text { soup, } \\
\text { main course, } \\
\text { dessert }\end{array}$ & & \\
\hline Lenan & $\begin{array}{l}\text { Moulton } \\
\text { Table cloth } \\
\text { Napkin }\end{array}$ & $\begin{array}{l}\text { Bentuk candle } \\
\text { Cock comb } \\
\text { Rising sun fan } \\
\text { Pyramid } \\
\end{array}$ & \\
\hline alat makan, & Cutleris: & $\begin{array}{l}\text { soup spoon } \\
\text { dinner knife, dinner fork dessert } \\
\text { knife, dessert fork }\end{array}$ & \\
\hline \multirow[t]{3}{*}{ Alat hidang } & Chinawere & $\begin{array}{l}\text { Soup cup and saucer } \\
\text { Coffe or tea cup and saucer } \\
\text { B \& B plate } \\
\text { Salt and papper shaker } \\
\text { Astray } \\
\text { Dinner plate } \\
\text { Dessert plate }\end{array}$ & \\
\hline & Glass ware & $\begin{array}{l}\text { Water goblet } \\
\text { Red wine glass } \\
\text { White wine glass }\end{array}$ & \\
\hline & Silver ware & & \\
\hline \multirow[t]{9}{*}{ Service } & Before & Serving Menu & After \\
\hline & Table set up & Apperitive juice & \multirow[t]{2}{*}{ Billing and thank you } \\
\hline & Guest coming & Appetizer, Clear up & \\
\hline & Sitting the guest & Soup, clear up & Farewall the guest \\
\hline & Giving menu & Clear up BB plate & \\
\hline & Ice water, bread and butter & Main course, clear aup & \\
\hline & & Dusting, crumbing down & \\
\hline & Expalin menu & Dessert, clear up & \\
\hline & Taking order, repeat, & Coffe or tea & \\
\hline
\end{tabular}


Tabel 4. Cakupan Materi Komik Table Manner

\begin{tabular}{|l|l|}
\hline \multicolumn{1}{|c|}{ Before } & Uraian \\
\hline Napkin, Informal, & Letakkan di pangkuan segera setelah duduk \\
\hline Napkin, formal & $\begin{array}{l}\text { Tunggu nyonya rumah meletakkan napkin di pangkuannya, } \\
\text { ikuti dengan cara yang sama }\end{array}$ \\
\hline & Saat meninggalkan meja sementara, letakkan serbet di kursi \\
\hline Memegang garpu dan sendok & $\begin{array}{l}\text { Setelah selesai makan, lipat serbet dan letakkan di sebelah } \\
\text { kiri tempat duduk }\end{array}$ \\
\hline Mulai makan & \\
\hline
\end{tabular}

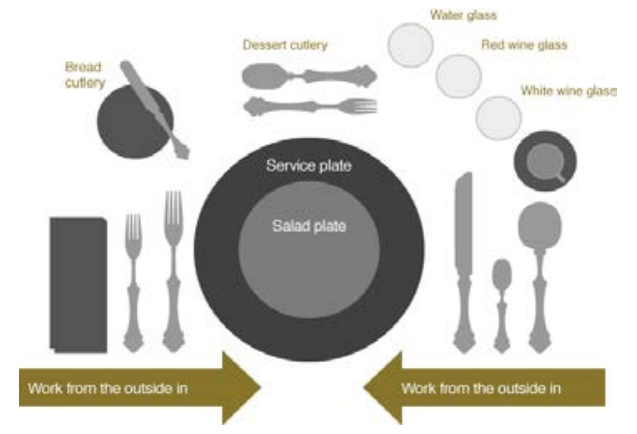

\section{SIMPULAN}

Pembuatan komik diawali dengan pembuatan Garis Besar Program Media. Dimana disini kita menentukan Mata pelajaran apa yang akan dibuat komik digital, dan tentunya penentuan tujuan pembelajaran, materi, standar kompetensi, kompetensi dasar, dan juga indikator. Tahap selanjutnya adalah membuat Story Board, yang merupakan penjabaran dari GBPM tadi dimana disitu pun sudah dimuat cerita (alur, tokoh, sudut pandang, visualisasi dan lain sebagainya). Story board ini lah yang akan memandu kita untuk membuat cerita yang utuh dalam komik digital dan tentunya sesuai dengan tujuan pembelajaran yang kita inginkan.

Teknis pembuatan komik digital ini tidak begitu sulit. Bagi yang sudah terbiasa menggambar, akan sangat mudah untuk membuatnya. Biasanya diawali dengan pembuatan sketsa, kemudian proses scanning, dan proses pewarnaan dan finishin gmenggunakan software grafis melalui komputer.
Komik digital sangat mudah untuk dikembangkan. Dengan kecanggihan teknologi yang terus berkembang saat ini, didukung dengan produsen komputer dan gadget yang ada di Indonesia yang juga mumpuni dalam dukungan hardware dan software. Indonesia tentu akan mampu membuat suatu media pembelajaran yang menarik, inovatif, dan tentunya memiliki hasil yang signifikan dalam meningkatkan hasil belajar siswa.

Komik digital dapat dikembangkan baik secara online maupun offline. Semua tergantung pada kebutuhan dan ketersediaan sarana dan pra sarana yang ada di lapangan.

Bagi guru,maupun dosen tentunya sangat mudah di era digital ini untuk membuat media yang kreatif dan disukai siswa. Sedangkan bagi siswa, belajar dengan media visual yang mumpuni, mempermudah penalaran dan pemahaman, tentunya akan sangat membantu dalam memecahkan masalah belajar di sekolah dan dimana saja.

\section{REFERENSI}

[1] Burden, P. R., \& Byrd, D. M. (1998). Methods for effective teaching. Boston: Allyn and Bacon.

[2] Cisco Public Information. (2012). A cisco networking academy point of view advancing assessment with technology, diperoleh dari www.cisco.com/go/trademarks tanggal 18 Mei 2012 
[3] Clauser, B. E., Harik, P. \& Clyman, S. G., (2000). The generalizability of scores for a performance assessment scored with a computer automated scoring system. Journal of Educational Measurement. Fall 2000, Vol. 37, No. 3, pp. 245-261

[4] Conner, C. (1991). Assessment and testing the primary school. Philadelphia: The Falmer Press

[5] Dick, W., \& Carey, L. (1996). The Systematic Design of Instruction (4th Ed.). New York: Haper Collins College Publishers.

[6] Griffin, P., \& Peter, N. (1991). Educational assessment and reporting. Sidney: Harcourt Brace Javanovich Publisher (Hambleton, 1991: 13).

[7] Huitt, W. (2001). Assessment, measurement and evaluation: Undergraduate version. Educational Psychology Interactive. Valdosta, GA: Valdosta State University. Retrieved (17 Nopember 2007), from http://chiron.valdosta.edu/whuitt/edpsyc/ edpmsevl.html

[8] Johnson, D. W., \& Johnson, R. T. (2002). Meaningful assessment, A manageable and cooperative process. Boston : Allyn and Bacon

[9] Kane, M. T. (2006). Validation. In Brennan, R. B. (Ed). Educational measurement $\left(4^{\text {th }}\right.$ ed) pp $17-64$. American Council on Education Praeger.

[10] Lunz, M. E., \& Bergstrom, B. A. (1994). An empirical study of computerized adaptive test administration conditions. Journal of Educational Measurement. Fall 1994, Vol. 31, No. 3, pp. 251-263.

[11] McIntire, S. A., \& Miller, L. A. (2000). Foundation of psychological testing. Boston: McGraw-Hill.

[12] Mehrens, W. A., \& Lehman, I. (1973). Measurement and evaluation in education and psychology. New York: Holt, Rinehart and Winston, Inc.
[13] Messick, S. (1989). Validity. In Robert L. Linn (Ed). Educational measurement ( $3^{\text {rd }}$ ed) pp. 13-103. New York: American Council on Education and Macmillan

[14] Neuman, W. L. (2003). Social research methods, qualitative and quantitative approaches $\left(5^{\text {th }}\right)$. Boston: Pearson Education Inc

[15] Oshima, T. C. (1994). The effect of speediness on parameter estimation in item response theory. Journal of Educational Measurement. Fall 1994, Vol. 31, No. 3, pp. 200-219.

[16] Pitkin, A. K. and Vispoel, W. P. (2001). Differences between self-adapted and computerized adaptive test: A meta-analysis. Journal of Educational Measurement. Fall 2001, Vol. 38, No. 3, pp. 235-241

[17] Reynolds, C. R., Livingston, R. B. \& Willson, V. (2010). Measurement and assessment in education 2nd edition: New Jersey: Pearson Prentice Hall

[18] Rodiguez, M. C. (2003). Construct equivalence of multiple-choice and constructed-response items: A random effects synthesis of correlation. Journal of Educational Measurement, Summer 2003, Vol. 40, No. 2, pp. 163-184

[20] Sumadi Suryabrata. (1981). Pengukuran dan penilaian pendidikan, (Kumpulan makalah penataran bimbingan dan konseling untuk tenaga pengajar di PT se Indonesia, edt). Jakarta: Dirjen Pendidikan (Suryabrata, 1981).

[21] Yahya Umar. (1996). Bahan penataran pengujian pendidikan. Jakarta: Puslitbangsisjian-Depdikbud 